\title{
Threat of mass resignation as a window of opportunity for questioning hospital service production structures in Finland
}

This article was published in the following Dove Press journal:

Risk Management and Healthcare Policy

6 July 2011

Number of times this article has been viewed

\author{
Lauri Kokkinen ${ }^{1,2}$ \\ Elina Viitanen' \\ 'School of Health Sciences, University \\ of Tampere, Tampere, ${ }^{2}$ Unit of \\ Expertise for Work Organizations, \\ Finnish Institute of Occupational \\ Health, Turku, Finland
}

Background: Service production structures of public health care, once established, have proved extremely difficult to change. For this study, we reviewed discussions that took place in management teams at a Finnish central hospital over a period of nine months. The aim of the research was to analyze whether the management team meetings brought forth new and radical alternatives as to how service production could be reorganized. In addition to this, we were also interested in any possible problems that could be solved using these alternative models of service production, and also how preconditions to the application of different alternatives came about and how they eventually concluded.

Methods: Our data were derived from 24 management team meetings that took place between August 2007 and May 2008, and were fully videotaped. Data were collected from eight different management teams; the meetings of each were videotaped three times. The management teams reviewed represented three different hierarchical levels, ie, top management, division management, and operational unit management. Data were analyzed according to theorybased content analysis. As a theoretical framework, we utilized Kingdon's model to enable us to understand why some issues and problems are brought to the agenda of the change process and go on to become concrete policies while others fail to do so.

Results: During the study period, a threat of mass resignation of nursing staff caused a considerable change to the agenda of the management team meetings, introducing alternatives with the potential to renew the existing structures of operation in a radical manner.

Conclusion: According to our analysis, the threat of mass resignation acted as a window of opportunity, linking the lack of nursing staff (problem) to operational and structural changes (alternative solutions).

Keywords: hospital, nursing staff, mass resignation, change

\section{Background}

Service production structures of public health care, once established, have proved extremely difficult to change. ${ }^{1-4}$ The outline provided by Ferlie et al states that the governing features of the operational structure of public health care and its management can be summarized into three main traditions: (1) political decision-making, (2) bureaucratic organization, and (3) strong professions. ${ }^{5}$ In reference to our earlier research, substantial discussion on professional management, ie, managerialism, has not succeeded in superseding these traditions in Finnish health care. ${ }^{6}$

From the viewpoint of Ferlie et al, ${ }^{5}$ we can maintain, first, that in addition to party and trade organizational political interest, health care organizations are also maintained by strong interests that relate to regional politics. In Finland, the municipalities are
Correspondence: Lauri Kokkinen Sammonkatu 36 G 82, 33540 Tampere, Finland

Tel +358405529559

Email lauri.kokkinen@uta.fi 
responsible for providing health care (Figure 1), and thus every municipal decision-maker has at least a theoretical incentive to offer as wide a range of health care services as possible in the hospitals within their catchment area. ${ }^{7}$ After all, health care does produce services that are highly appreciated by voters, and the health care industry is also one of largest employers in many Finnish municipalities.

Secondly, also from the viewpoint of Ferlie et al, we can say that health care organizations, and hospitals in particular, continue to set a good example on how work can be bureaucratically organized. Hospital organizations can be considered bureaucratic, as a result of their large size, hierarchical structure, and the highly specialized work distribution that prevails in many hospitals. The latest research on Finnish hospital organization supports the view that many dysfunctions commonly associated with bureaucracy continue to stigmatize hospital organizations. ${ }^{8}$

Thirdly, based again on the outline by Ferlie et al, we can maintain that in health care the professional identity of an individual employee, and also their position in the organization, is to a large extent determined by their socialization within their own professional group. The hierarchy of prestige between different professionals is invariably high within hospital organizations, and many researchers have paid special attention to the fact that crossing the barriers between different professional groups seems to be exceedingly difficult. ${ }^{9,10}$

In this paper, we are interested in studying the prerequisites for crossing the barriers that these three traditions uphold inside and between hospital organizations. We point to new alternatives for service production that cross the barriers of regional politics, barriers between different organizational units (bureaucratic barriers), and barriers between different professional groups (professional barriers).

In the research literature, the possibility, or necessity, of crossing the aforementioned institutionalized barriers has often been associated with a certain crisis or other such attention-drawing event that acts as a trigger. ${ }^{11,12}$ In the previous research literature, pressure caused by labor has seldom been recognized as this kind of a structural changeinducing factor. In studies where, for example, the adequacy of staff is viewed as one (but not crucial) factor to the implemented structural changes or as a background to future change alternatives, the labor involved have invariably been doctors, around whom health care organizations are built. In contrast, cases in which another professional health care group has collectively been able to tender its work contribution have not been connected to the analysis of factors behind the changes in health care service production structure, nor have they been analyzed as a factor leading to changes in health care structure.

The use of so-called hard measures of work action has been extremely rare in Finland during recent decades. The Union of Health and Social Care Professionals organized a work action in the fall and winter of 2007, and as such this was an exceptional event. Between October 15, 2007 and November 19, 2007, this trade organization used the threat of mass resignation to pressure employers into meeting their demands to increase the wage level for nursing staff. In this paper we ask whether the threat of mass resignation of nursing staff opened up a window of opportunity to question the main traditions (as described previously) that uphold service production within the public health care system.

\begin{abstract}
Health care services in Finland are produced by the public, private, and so-called third sector organizations. The Finnish Public Health Act (66/1972) transferred responsibility for the arrangement of primary health care services to the municipalities. Municipalities may produce the services themselves or via purchase from other municipalities or private and third-sector service providers. Primary health care is mostly given in the country's 170 (March 2011) health centers. The Specialized Medical Care Act (1062/1989) required that the municipalities additionally provide special health care for their residents. There are 20 hospital districts in Finland, of which five are university hospital districts. Each municipality is associated with a hospital district that provides specialized medical care for the residents of its member municipalities. There is a central hospital in each of the 20 hospital districts. In addition, the country is divided into five expert catchment areas for the provision of expert-level medical care. Each catchment area includes a hospital district with a university hospital. Both of these service production organizations, ie, health centers and public hospitals, collect a client fee, but the majority of the services are paid for by the municipality, meaning they are tax-funded services. The highest decision-making power in both, ie, the municipalities and joint municipalities (hospital districts) is used by a political organ. In 2011, there were major revisions ongoing to the Finnish Health Care Act and the municipal and service structures.
\end{abstract}




\section{Methods}

Theory

We used Kingdon's model as a theoretical framework of analysis to enable us to understand why some issues and problems are able to appear on the agenda of change and go on to become concrete operational policies, while others fail to do so. ${ }^{13}$ This model has previously been used first and foremost to analyze institutional change, and the lack thereof, in the public sector, for example, health care. According to Kingdon's model, in order for a change to be implemented, prerequisites in three different areas need to occur. These prerequisites are: (1) a definition of the problem at hand, (2) determination of the possible solutions, and (3) the political atmosphere and decision-making. If the prerequisites of all three areas are met simultaneously, a window of opportunity occurs. This is what enables a certain solution to a problem to become a concrete operational policy.

Behind Kingdon's model lies the famous "garbage can" theory of organizational decision-making devised by Cohen et al. ${ }^{14}$ Their theory was the first to emphasize the notion that solutions are not always initially crafted to solve given problems but rather that they float free in search of problems to become attached to. From the point of view of this study, it seemed critically important also to include in the analysis the effect of political atmosphere on decision-making. In Kingdon's model, the stream of politics is relatively independent of the other two streams (problems and solutions), but the model states that dynamic and special needs caused by a political event can turn the agenda upside down. Political events can cause an issue and its solution to be put on the agenda, or to be taken off it. In Kingdon's model, these three streams act according to their own logic, until a window of opportunity occurs when all three streams coincide, and then a given issue may transform into a concrete policy. Thus, a pressing issue is attached to a plausible solution that meets the requirements of political feasibility.

From the point of view of this study, Kingdon's model developed in a very different context seemed to suit well the Finnish hospital decision-making process that our research was investigating.

\section{Data}

Our data were gleaned from 24 management team meetings that took place between August 2007 and May 2008 in a medium-sized Finnish central hospital. All meetings were videotaped in their entirety. This particular central hospital provides health care services to more than 200,000 inhabitants in the area and also acts as central government for a hospital district owned by approximately 20 different municipalities. The data we collected from the central hospital came from eight different management groups, the meetings of which were videotaped three times each. The management teams videotaped represented three different hierarchical levels: top management, division management, and operational unit management. In the meetings of top management, the highest official management and its representatives were present together with all the leaders of the division areas. The meetings of the division management included meetings of the conservative, operational, and psychiatric divisions. The operational unit management team meetings took place in the units of pediatrics, pulmonary diseases, surgery, and child psychiatry. In addition to the authors of this paper, a third researcher took part in videotaping the meetings. The video data consisted of nearly 40 hours of taped material.

We collected and used the data with permission from top management of the studied hospital and with permission from every member of the management teams observed.

\section{Analysis}

The aim of this study was to analyze whether management team meetings bring forth new and radical alternatives related to the organization of service production. In addition to this, we were also interested in how the problems and issues associated with structural solution alternatives were produced, and also in how prerequisites to implementation of a solution were brought about and concluded. Instead of the usual more linguistic methods of study, we chose a more realistic way to implement our research. ${ }^{15}$ Our method was a theorybased content analysis, which was structured according to the phases introduced by Kingdon in his model. ${ }^{16,17}$

First, our interest was focused on whether the data included solution alternatives as to how work can be organized, which would cross the barriers of regional politics, barriers between different organizational units (bureaucratic barriers), or barriers between different professional groups (professional barriers), as established by Ferlie et al. ${ }^{5}$ At the beginning of the analysis process, three different categories of solution alternatives were coded, each of which could be seen as barrier-crossing. The analysis unit in this process was the concept. These concepts were often longer statements but sometimes were as short as only a few sentences. The solution alternatives that could be seen as crossing regional political barriers mainly referred to a new kind of cooperation between the central hospitals of the two neighboring hospital districts. The solution alternatives that were summoned under the bureaucracy category always contained the idea of moving operations or resources across the borders 
of either the area of operation or the different operation units inside the hospital organization. Professional solution alternatives referred almost without exception to a new division of labor between doctors, registered nurses, and practical nurses.

During the follow-up work, we decided to transcribe the video material in its entirety. This enabled us to verify our observations also through literal material. After this step, we placed the different analyses from the management meetings of each level into the same time line to form a time series. With the help of this time series, we were able to combine into our analysis different timebound events that had an impact on all three hierarchical levels of the management groups. Thus, it was possible to compare the solution alternatives suggested at the time of the threat of mass resignation of nursing staff to the solutions posed at other times. In the results section of this paper, we present the different barrier-crossing solution alternatives that occurred before, during, and after the threat of mass resignation.

Secondly, on the other hand, in accordance with the theoretical framework selected for this paper, we were also interested in the recognition of the problem to be solved, and how that problem was interpreted before and during the threat of mass resignation. The starting point of our analysis was how the problem was formed on a national level. The data for this part of the analysis were formed from opinion polls, documented discussions, and the literature at the time that the Union of Health and Social Care Professionals industrial action took place. These data enabled us to show that the labor question became a nationwide political dilemma, which was explicated into a problem that required a solution. From our video data, we observed how the problem agenda was formed in the hospital of interest. In the results section of this paper, the manifestation of the problem in the hospital of interest is depicted by narration and direct quotes.

Thirdly, in accordance with the selected theoretical framework, we were interested in how the political atmosphere manifested in our data during the threat of mass resignation. In addition to the videotaped material, this part of the analysis also drew on observation journals kept during the videotaping process, as well as the official hospital records of the meetings. As suggested in the previous research literature, we paid special attention to any references to regional politics, trade organization politics, and party politics while analyzing our data. We also observed some depoliticizing that could be read from between the lines, ie, when different barrier-crossing solution alternatives were discussed, there were no such obstacles related to regional, trade organizational, or party politics mentioned, as could have been expected based on the previous research literature.

\section{Results \\ Problem formation on a national level}

Previous job action in the health care industry in Finland took place in 1995 in the middle of an economic recession, and quickly lost the support of the public. ${ }^{18}$ The salary increases gained beyond the general level were as low as around $1 \%$, and this guaranteed that discussion on how demanding the work is in the health care industry and how the wages correlate poorly with this, would be continued in the near future. In the fall of 2007, the question of wages in the health care industry again reached the national agenda. This was preceded by the 2007 parliamentary elections, after which the Finnish government was formed by the Centre Party, National Coalition Party, Green League, and the Swedish People's Party of Finland. The election promises of all of the major parties had included a wage increase in all the municipal industries dominated by women, such as health care, with the help of the government. However, resistance from the employers' organizations meant that the government was unable to deliver on this promise. In the fall of 2007, the parliamentary opposition, ie, the Social Democratic Party of Finland, Left Alliance, Christian Democrats of Finland, and True Finns, motioned the government on this matter. ${ }^{19}$

It was essential to formation of the problem agenda that, in addition to the opposition parties, most representatives of the government parties also expressed their concerns that the nursing staff was underpaid, both during and after the elections. According to opinion polls conducted by the Finnish Broadcasting Company, the Union of Health and Social Care Professionals' industrial action had strong support from the public, regardless of party politics, from the very beginning. ${ }^{20}$ After the Union of Health and Social Care Professionals rejected the offer by the employer organizations on October 15, it announced that it was stepping up its game and would now put pressure on employer organizations, with the threat of mass resignation.

\section{Hospital problem agenda}

In the hospital we observed for this research, the question of availability of skilled staff was already on the agenda of the management teams when we first began our videotaping in August 2007. The discussion brought to the table the fact that, during the previous few years, the hospital district had struggled extensively to develop the payroll system and labor policy in general. What is really interesting is that when the threat of mass resignation was realized, many members of the nursing staff consistently stated that they were sorry for the disorder and confusion caused by the tough measures used in the course of their industrial action. 
However, the nursing staff's commitment to industrial action was strong and, as in the rest of the country, the most prominent threats of resignations were aimed at the most critical units - for example, the emergency room and the intensive care unit, where up to one half of the nursing staff was threatening to resign. From the point of view of the problem agenda, it is also noteworthy that, throughout the industrial action, the hospital had very little information about the negotiations of the board to mediate the problem at the national level. One member of the top management team described the situation in the following manner: "We have to live like this [the realization of resignations] will happen, and we cannot make any plans at this late hour."

\section{Solution alternatives}

There were no suggestions regarding the crossing of regional political, bureaucratic, or professional barriers in the only meeting that took place before the threat of mass resignation.

During the threat of mass resignation, solution alternatives regarding crossing of the aforementioned barriers were often on the agenda. The solutions containing regional political barrier-crossing referred mainly to cooperation among the central hospitals located in the two neighboring hospital districts. The presentation of this solution alternative could, for example, begin along these lines:

"At the psychiatric division we already agreed that from ... about twenty or so patients can come to us. They will try to maintain some psychiatry at their end, but they will have to make clear cuts. Those who need inpatient care will come to us, and they will try to maintain their psychiatry mainly through outpatient care."

The alternatives summarized at the bureaucratic category always contained the idea of crossing the barriers between the different operational fields or units within the central hospital. Discussion typically began in this fashion:

"What is positive about this situation is that there are almost no resignations at many of the clinics. This means that we can make serious reductions at the clinical operations and then move resources from there into units that need to be secure, like for instance the ER and ..."

Professional alternatives concerned a new distribution of labor on the axis of doctors, registered nurses, and practical nurses. Discussions about the solution to this issue began, for example, in this way:

"Let's take a close look at the way we use practical nurses. We need to think hard to make sure that practical nurses are utilized to the absolute fullest, within the limits of their training and qualifications. At the moment we have excess resources of practical nurses and they will have to be able to do ..."

After the threat of mass resignation was over, regional political, bureaucratic, and professional barrier-crossing alternatives were put on the agenda far less often. Table 1 summarizes the prevalence of different barrier-crossing solution alternatives before, during, and after the threat of mass resignation.

In addition to the number of solutions during and after the threat of mass resignation, it was important to assess the purpose of the solutions. During the threat, solutions were connected without exception to the question of adequacy of staffing but not always after the threat was withdrawn. After the threat of mass resignation was over, discussion on the adequacy of staff also came up before Christmas, long holidays, and before summer holidays, but during these times no radical solution alternatives to reorganize service production came up.

\section{Political atmosphere}

During the threat of mass resignation, questions on treating patients and making the necessary changes became depoliticized in the central hospital we observed. First - albeit this was in a meeting that took place before the threat of resignation - the prevailing regional boundaries of the hospital district did not dictate the limits of service production. As was stated by one of the leading officials of the hospital: "In this case [during the threat of mass resignation] we need to prioritize operations so that the urgent matters of other hospital districts will be taken care of before our own less urgent ones." And the question was not only about treating patients as such, but regional politics also lost its grip on labor questions as well. Another official in a leading position led the discussion on optimizing the use of the available labor:

"This [moving staff across districts] brings a lot of administrative issues. But this is a possible solution and I'm sure it's one we can make in a good spirit. I mean nobody will start counting pennies in a situation like this."

Secondly, the claim that decision-making became depoliticized was also verified when we reviewed the attention that was paid to trade organizations in management team meetings that took place during the threat of mass resignation. When analyzing the changes and continuities of the health care industry, usually the trade organizations representing the strongest employee group, ie, the doctors, take the center stage. ${ }^{1-3,2}$ Based on the research literature, it can justifiably be reasoned that under normal circumstances nobody wants to aggravate strong trade organizations by making reform suggestions that are too radical. Instead, in the management team meetings where solution alternatives that radically crossed the traditional 
Table I The prevalence of barrier-crossing solution alternatives in management teams (number of solution alternatives and posed solution alternatives per meeting before, during, and after the threat of mass resignation)

\begin{tabular}{|c|c|c|c|}
\hline & $\begin{array}{l}\text { Before the threat of mass resignation } \\
\text { (number of meetings }=I \text { ) }\end{array}$ & $\begin{array}{l}\text { During the threat of mass resignation } \\
\text { (number of meetings }=2 \text { ) }\end{array}$ & $\begin{array}{l}\text { After the threat of mass resignation } \\
\text { (number of meetings }=2 \mathrm{I} \text { ) }\end{array}$ \\
\hline $\begin{array}{l}\text { Solution } \\
\text { alternatives } \\
\text { crossing }\end{array}$ & $\begin{array}{l}\text { Solution } 0 \\
\text { alternatives }\end{array}$ & $\begin{array}{l}\text { Solution } 8 \\
\text { alternatives }\end{array}$ & $\begin{array}{l}\text { Solution } 10 \\
\text { alternatives }\end{array}$ \\
\hline $\begin{array}{l}\text { regional } \\
\text { political } \\
\text { barriers }\end{array}$ & $\begin{array}{l}\text { Solution } 0 \\
\text { alternatives } \\
\text { per meeting }\end{array}$ & $\begin{array}{l}\text { Solution } 4 \\
\text { alternatives } \\
\text { per meeting }\end{array}$ & $\begin{array}{l}\text { Solution } 0.5 \\
\text { alternatives } \\
\text { per meeting }\end{array}$ \\
\hline $\begin{array}{l}\text { Solution } \\
\text { alternatives } \\
\text { crossing }\end{array}$ & $\begin{array}{l}\text { Solution } 0 \\
\text { alternatives }\end{array}$ & $\begin{array}{l}\text { Solution } 5 \\
\text { alternatives }\end{array}$ & $\begin{array}{l}\text { Solution } 7 \\
\text { alternatives }\end{array}$ \\
\hline $\begin{array}{l}\text { bureaucratic } \\
\text { barriers }\end{array}$ & $\begin{array}{l}\text { Solution } 0 \\
\text { alternatives } \\
\text { per meeting }\end{array}$ & $\begin{array}{l}\text { Solution } 2.5 \\
\text { alternatives } \\
\text { per meeting }\end{array}$ & $\begin{array}{l}\text { Solution } 0.3 \\
\text { alternatives } \\
\text { per meeting }\end{array}$ \\
\hline $\begin{array}{l}\text { Solution } \\
\text { alternatives } \\
\text { crossing }\end{array}$ & $\begin{array}{l}\text { Solution } 0 \\
\text { alternatives }\end{array}$ & $\begin{array}{l}\text { Solution } 5 \\
\text { alternatives }\end{array}$ & $\begin{array}{l}\text { Solution } 5 \\
\text { alternatives }\end{array}$ \\
\hline $\begin{array}{l}\text { professional } \\
\text { barriers }\end{array}$ & $\begin{array}{l}\text { Solution } 0 \\
\text { alternatives } \\
\text { per meeting }\end{array}$ & $\begin{array}{l}\text { Solution } 2.5 \\
\text { alternatives } \\
\text { per meeting }\end{array}$ & $\begin{array}{l}\text { Solution } 0.2 \\
\text { alternatives } \\
\text { per meeting }\end{array}$ \\
\hline
\end{tabular}

and also professional barriers were presented, the approval of trade organizations was not on the agenda at all.

Thirdly, it is possible that depoliticizing also took place in the form of party politics. Earlier research gives some indication that, in Finland, the cooperation among neighboring hospital districts that have opposing political compositions has also been hindered by party political tensions. ${ }^{22}$ However, during the threat of mass resignation, the question of whether the solution alternatives would be approved of in the political decision-making was not brought to the table at all.

\section{Discussion}

The pressure caused by organized labor manifested itself during the threat of mass resignation as a force that compelled the decision-makers of a public hospital organization to bring to the agenda other alternatives besides the ones that could be executed within a strictly limited institutional framework. However, the rationale of the participants who brought out such radical solutions seemed to deviate considerably. From the perspective of the first extreme, the solutions that were brought to the agenda were seen as the last possibility of reacting to a crisis. For example, when discussing the possibility of moving some of the duties of registered nurses to practical nurses, some were eager to maintain how difficult it would be to restore the job descriptions once the situation normalized: "If we now change the job descriptions, it will be impossible to change them back in the future. If we choose to take that path, that will be the path we in this hospital district will need to follow." The participants were ready to pin the posed radical solution alternatives to the problem on the agenda, but only in an extreme emergency. From the perspective of the other extreme, the participants specifically managed to bring up the agenda alternatives that would renew the existing service production structures. The potential and need for these changes was recognized before the threat of mass resignation, but their implementation had failed to take place earlier: "I've been telling you for a couple of years now that it is actually pretty irrational that both our hospital and ... hospital take care of deliveries. Now we can really see if centralization will be the answer." From this view point, the crisis caused by the threat of mass resignation actually offered the opportunity to cross the traditions. Based on our analysis, it can be stated that the window of opportunity to question the traditions that maintain service production structures really opened up for the duration of the threat of mass resignation in the management teams of the hospital organization we observed. The general political atmosphere enabled, for the duration of the threat of mass resignation, the possibility of bringing forth new radical solution alternatives and pinning them to the problem on the agenda. On the other hand, during the crisis, some members of the management teams were consciously trying to keep the window of opportunity closed, or at least half shut.

When the threat of mass resignation concluded, the window of opportunity was closed. At this time the problem on the agenda of the management teams was, at least to a certain extent, solved by the contract between the Union 
of Health and Social Care Professionals and the municipal employee. The political atmosphere was no longer favorable to radical crossing of the traditional barriers, and the solution alternatives posed were once again shelved to await new problems they could be attached to.

The window for implementing the alternatives suggested at the management team meetings had no time to open up during the threat of mass resignation. The duration of the crisis was too short for this to occur. It is also likely that all of the proposed solution alternatives could not have been implemented as such. It should be kept in mind that the video material for this study was collected from one Finnish central hospital only.

\section{Conclusion}

Making changes to health care service production structures, once set, has proven to be extremely difficult. This study focuses attention on the fact that without its largest employee group, nursing staff, a hospital organization could not operate without making some radical changes. The pressure caused by the organized industrial action of the nursing staff brought solution alternatives to the agenda of our research hospital that would have renewed the existing service production structures in a radical way. However, the solutions brought onto the agenda were never implemented because the crisis dissolved.

\section{Acknowledgments}

The authors would like to thank the hospital district of EteläPohjanmaa for providing the financial support to carry out this research project. The authors would also like to thank LiinaKaisa Tynkkynen for providing help with collecting data.

\section{Disclosure}

The authors declare that they have no competing interests in this work.

\section{References}

1. Ham C. Health Policy in Britain. Basingstoke, UK: Palgrave; 1999.

2. Scott WR, Ruef M, Mendel PJ, Caronna CA. Institutional Change and Health Care Organizations: From Professional Dominance to Managed Care. Chicago, IL: University of Chicago Press; 2000.

3. Salter B. The New Politics of Medicine. Basingstoke, UK: Palgrave; 2004.

4. McKee L, Ferlie E, Hyde P. Organizing and Reorganizing: Power and Change in Health Care Organizations. Basingstoke, UK: Palgrave McMillan; 2008.
5. Ferlie E, Ashburner L, Fitzgerald L, Pettigrew A. The New Public Management in Action. Oxford, UK: Oxford University Press; 1996.

6. Viitanen E, Kokkinen L, Konu A, Simonen O, Virtanen JV, Lehto J. Johtajana Sosiaali- ja Terveydenhuollossa [Leadership in Social Services and Health Care]. Vammala, Finland: Development Fund for Municipal Fields; 2007.

7. Teperi J, Porter ME, Vuorenkoski L, Baron J. The Finnish Health Care System: A Value-based Perspective. Helsinki, Finland: Sitra; 2009.

8. Virtanen JV. Johtajana sairaalassa. Johtajan toimintakenttä julkisessa erikoissairaalassa keskijohtoon ja ylimpään johtoon kuuluvien lääkärija hoitajataustaisten johtajien näkökulmasta [Leadership in hospital. The field of a manager in a specialized public hospital from the perspective of managers with a background in medicine or nursing]. $\mathrm{PhD}$ thesis. Turku School of Economics; 2010.

9. Denis J-L, Lamothe L, Langley A, Valette A. The struggle to redefine boundaries in health care systems. In: Brock D, Powell M, Hinings CR, editors. Restructuring the Professional Organization. London, UK: Routledge; 1999.

10. Ferlie E, FitzGerald L, Wood M, Hawkins C. The nonspread of innovations: the mediating role of professionals. Acad Manage J. 2005; 48:117-134.

11. Greenblatt M, Myron R, Sharaf E, Stone M. Dynamics of Institutional Change: The Hospital in Transition. Washington, DC: Beard Books; 2003.

12. Harrington C, Estes CL. Health Policy: Crisis and Reform in the US Health Care Delivery System. 4th ed. London, UK: Jones and Bartlett; 2004.

13. Kingdon J. Agendas, Alternatives and Public Policies. New York, NY: Harper Collins; 1984.

14. Cohen MD, March JG, Olsen JP. A garbage can model of organizational choice. Admin Sci Q. 1972;17:1-25.

15. Bottorff J. Using videotaped recordings in qualitative research. In: Morse JM, editor. Critical Issues in Qualitative Research Methods. London, UK: Sage Publications; 1996.

16. Strauss AL. Qualitative Analysis for Social Scientists. Cambridge, UK: Cambridge University Press; 1987.

17. Silverman D. Doing Qualitative Research. 2nd ed. London, UK: Sage Publications; 2004.

18. Nummila H. Työtaistelut. [Job action]. In: Tilastokeskus, editor. Suomen Vuosisata. [Finnish Century]. Helsinki, Finland: Tilastokeskus; 1999.

19. Välikysymys $1 / 2007$. Hoidon laadun ja ammattitaitoisen työvoiman turvaaminen [Motion 1/2007: ensuring the quality of care and adequacy of trained staff]. Available at: http://www.eduskunta.fi/faktatmp/utatmp/ akxtmp/vk_1_2007_p.shtml. Accessed April 10, 2011.

20. Suomen yleisradio. Kysely: Enemmistö hyväksyy Tehyn työtaistalun [Finnish Broadcasting Company: opinion poll; most people are behind the Tehy job action]. Available at: http://www.yle.fi/ uutiset/kotimaa/2007/10/kysely_enemmisto_hyvaksyy_tehyn_ tyotaistelun_254583.html. Accessed April 10, 2011.

21. Salter B. The Politics of Change in the Health Service. London, UK: MacMillan; 1998.

22. Kokkinen L, Lehto J. Changing health care from inside out: Policy entrepreneur questioning ophthalmology service production in Finland. International Journal of Public and Private Health Care Management and Economics. 2011;1(1):16-27.

\section{Dovepress}

\section{Publish your work in this journal}

Risk Management and Healthcare Policy is an international, peerreviewed, open access journal focusing on all aspects of public health, policy, and preventative measures to promote good health and improve morbidity and mortality in the population. The journal welcomes submitted papers covering original research, basic science, clinical \& epidemio- logical studies, reviews and evaluations, guidelines, expert opinion and commentary, case reports and extended reports. The manuscript management system is completely online and includes a very quick and fair peerreview system, which is all easy to use. Visit http://www.dovepress.com/ testimonials.php to read real quotes from published authors. 